\title{
A tailor-made self-sufficient whole-cell biocatalyst enables scalable enantioselective synthesis of (R)-3-quinuclidinol in a high space-time yield
}

Qian Chen, ${ }^{\dagger}$ Baogang Xie, ${ }^{\ddagger}$ Liping Zhou ${ }^{\dagger}$ Lili Sun,$\dagger$ Shanshan $\mathrm{Li}^{\dagger}{ }^{\dagger}$ Yuhan Chen, ${ }^{\dagger}$ Shan Shi, ${ }^{\dagger}$ Yang Li, ${ }^{\dagger}$ Mingan $\mathrm{Yu}^{\dagger}$ and $\mathrm{Wei} \mathrm{Li}^{*},{ }^{\dagger}$

$\dagger$ Department of Medicinal Chemistry, School of Pharmacy, Chongqing Medical University, Chongqing 400016, P. R. China

$\$$ Office of School of Pharmacy, Chongqing Medical University, Chongqing 400016, P. R. China

*Corresponding author, E-mail: Li_wei@cqmu.edu.cn

Fax: +86236848 5161. Tel: +862368485161 
Table S1. Asymmetric synthesis of (R)-3-quinuclidinol catalysed by whole-cell E.coli-MLG, E.coli-GLM, and a combination of E.coli-MlQG and E.coli-GDH.

\begin{tabular}{llll}
\hline & \multicolumn{3}{c}{ Conversion yield $(\%)$} \\
\cline { 2 - 4 } Time $(\mathrm{h})$ & MLG & GLM & MlQR + GDH \\
\hline 1.0 & 33 & 23 & 10 \\
2.0 & 61 & 36 & 17 \\
3.0 & 85 & 51 & 26 \\
4.0 & 94 & 68 & 38 \\
4.5 & 100 & 87 & 40 \\
\hline
\end{tabular}

Reaction conditions: 3 -quinuclidinone $(0.5 \mathrm{mmol})$, appropriate amount of lyophilized cells (1.6 mg), D-glucose (1.5 equivalent), $0.1 \mathrm{mM}$ NADH, $0.1 \mathrm{mM} \mathrm{NAD}{ }^{+}$, PBS (pH7.0), total volume of $10 \mathrm{~mL}, \mathrm{pH}$ was kept at 7.0 with $\mathrm{NaOH}, 30{ }^{\circ} \mathrm{C}$, conversion yield and ee value was determined by GC analysis. 
HHHHHHMRLENKKAIVTGGAGGIGRATSIALAAEGAAVAVVDLNVEAAEAVAAEIREAG

4465.76

2308.516

GTAVAISADVSSEPDIERVIATAVAEFGGVDVVFNNAGIIRRTTAVETTVEEWDRVFGVNVRS

1703.904

IFLMCKHIVPIMEAAGGGSIINTGSGWGLKGGGQAISYCASKGAVVNMTRALAIDHGPAGI

2256.446

$\overline{\text { RVNSVNPGDVNTGMLREEARQLAQDTNAFLAEAADRPLRRMGEPHEVAQAVVWLASDD }}$

SSYVTGSALVVDGGGIAGGGGSMYTDLKDKVVVVTGGSKGLGRAMAVRFGQEQSKVVVN

YRSNEEEALEVKKEIEQAGGQAIIVRGDVTKEEDVVNLVETAVKEFGTLDVMINNAGVENP

4252.642

VPSHELSLENWNQVIDTNLTGAFLGSREAIKYFVENDIKGNVINMSSVHEMIPWPLFVHYA

ASKGGMKLMTETLALEYAPKGIRVNNIGPGAIDTPINAEKFADPEQRADVESMIPMGYIGN

2105.32

PEEIASVAAFLASSQASYVTGITLFADGGMTKYPSFQAGRG

Figure S1. Peptide mass fingerprint of purified recombinant MLG enzyme. The sequence of the identified peptides were shaded and underlined. Molecular mass of each peptide was indicated in Da. Linker sequence in the fusion enzyme MLG was marked in red. 


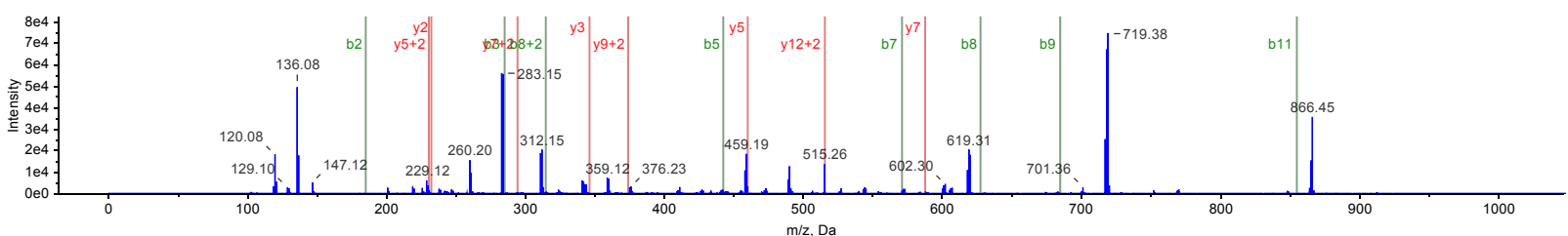

(1). AIVTGGAGGIGR

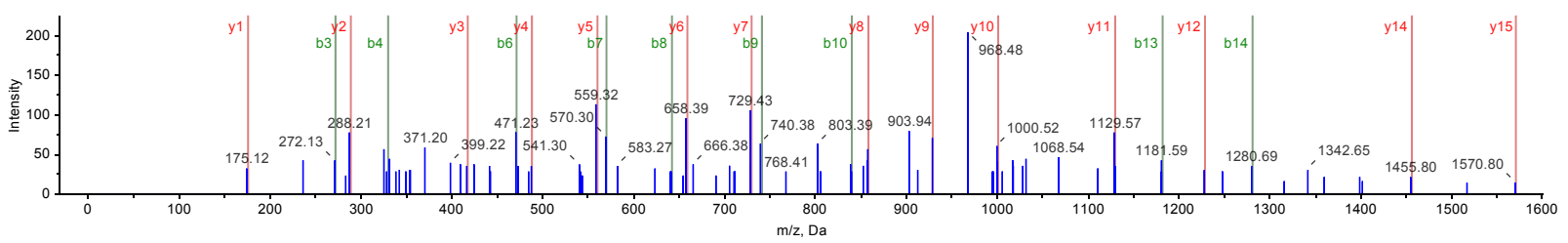

(2). AAEGAAVAVVDLNVEAAEAVAAEIR

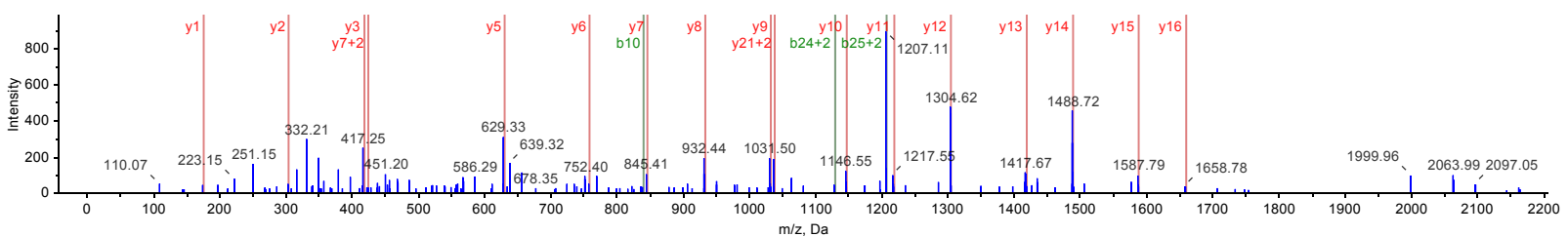

(3). AAEGAAVAVVDLNVEAAEAVAAEIREAGGTAVAISADVSSEPDIER

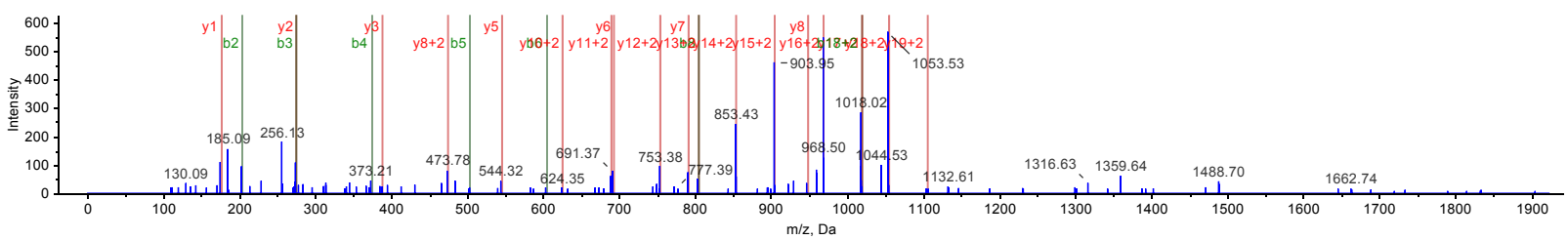

(4). TTAVETTVEEWDRVFGVNVR

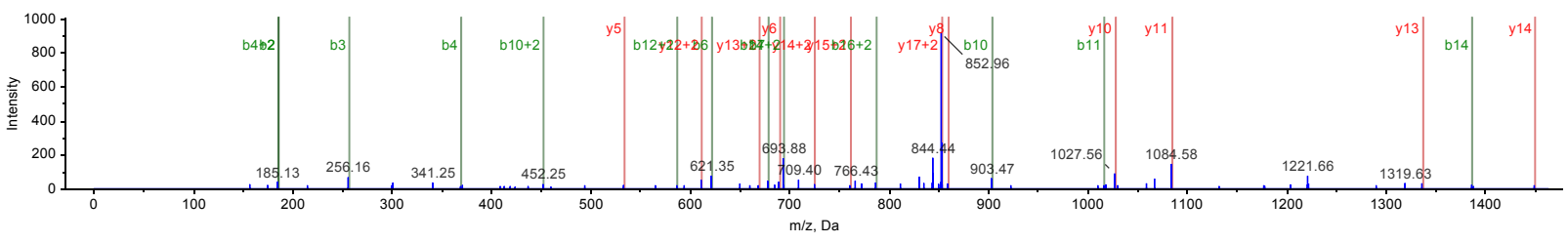

(5). ALAIDHGPAGIRVNSVN

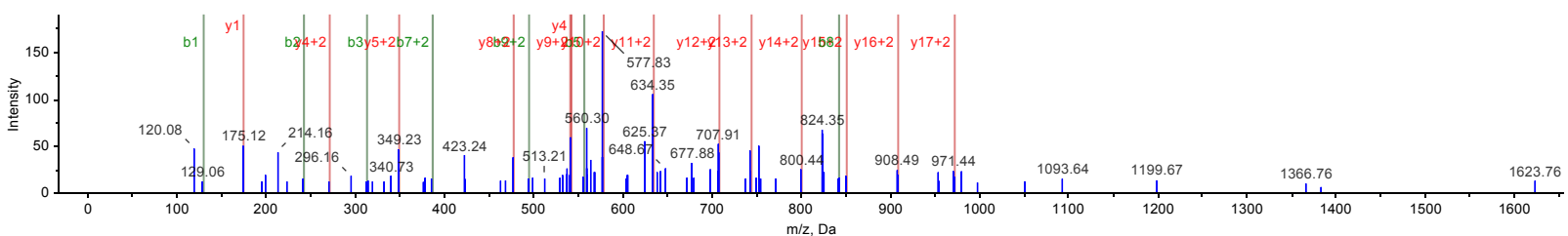

(6). QLAQDTNAFLAEAADRPLRR 


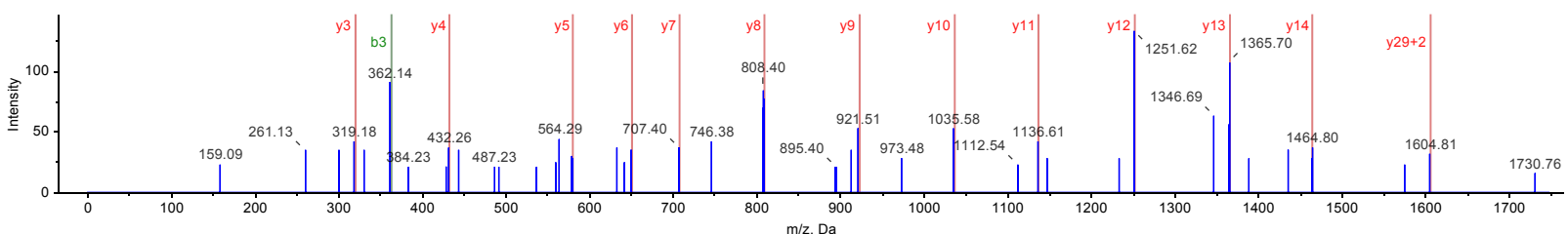

(7). DVMINNAGVENPVPSHELSLENWNQVIDTNLTGAFLGSR

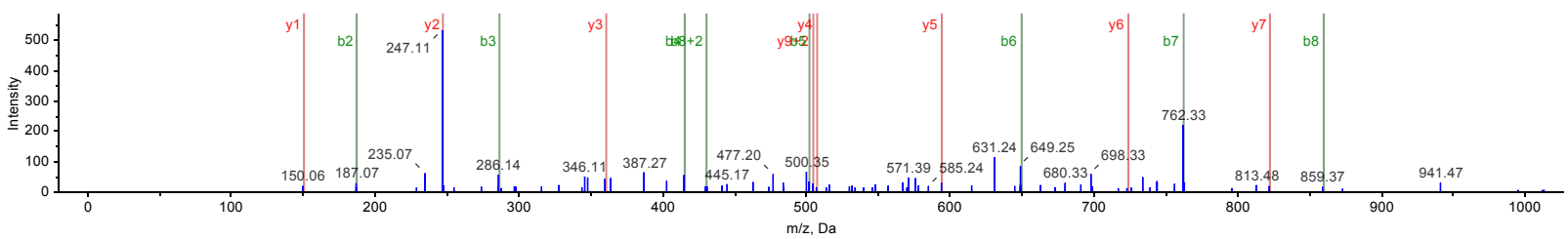

(8). ADVESMIPM

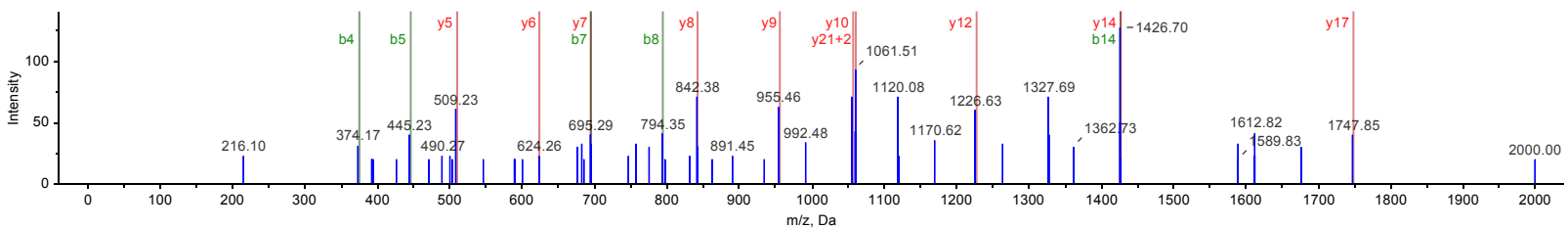

(9). ASSQASYVTGITLFADGGMTK

Figure S2. MS spectra of each of identified peptide in the fusion enzyme MLG. 

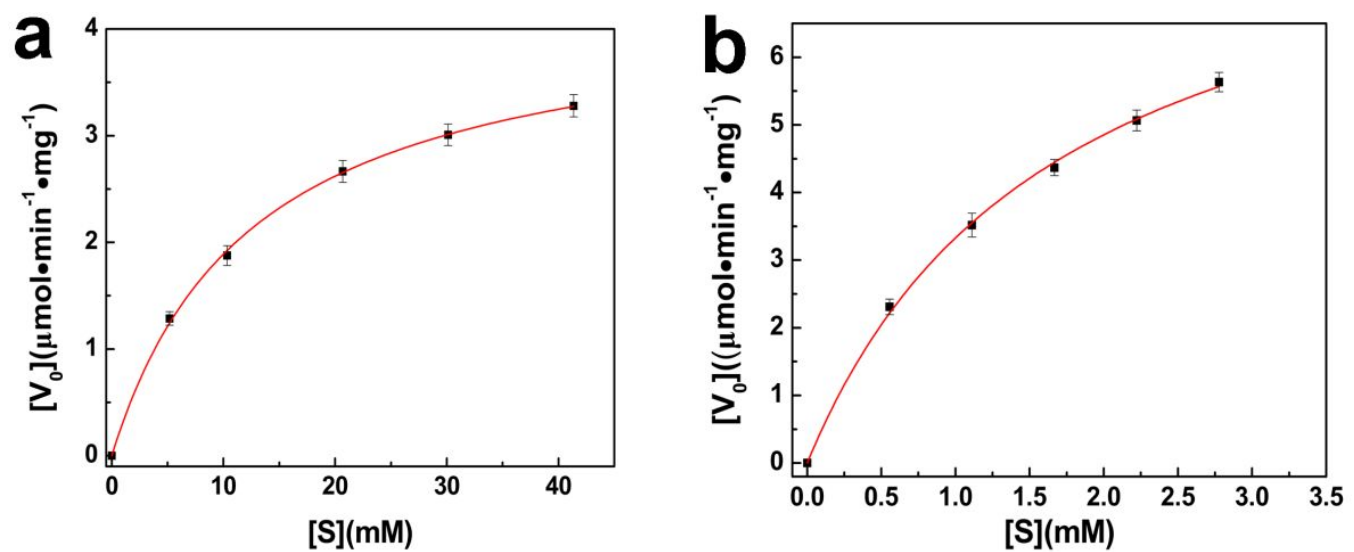

Figure S3. Substrate kinetic of activities for the fusion enzyme MLG. a) ketoreductase (MlQR) in the MLG at concentrations of 3-quinuclidinone as variants ranging from 0-40 $\mathrm{mM}, \mathrm{b})$ cofactor regenerating enzyme (GDH) in the MLG at concentrations of glucose as variants in the range of $0-2.7 \mathrm{mM}$. 


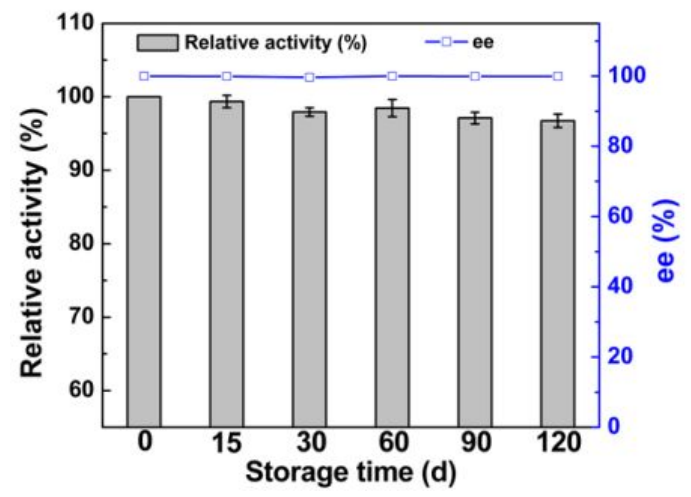

Figure S4. The influence of long storage period on the catalytic performance of whole-cell self-sufficient biocatalysts. The biotransformation reaction was carried out under standard conditions. 

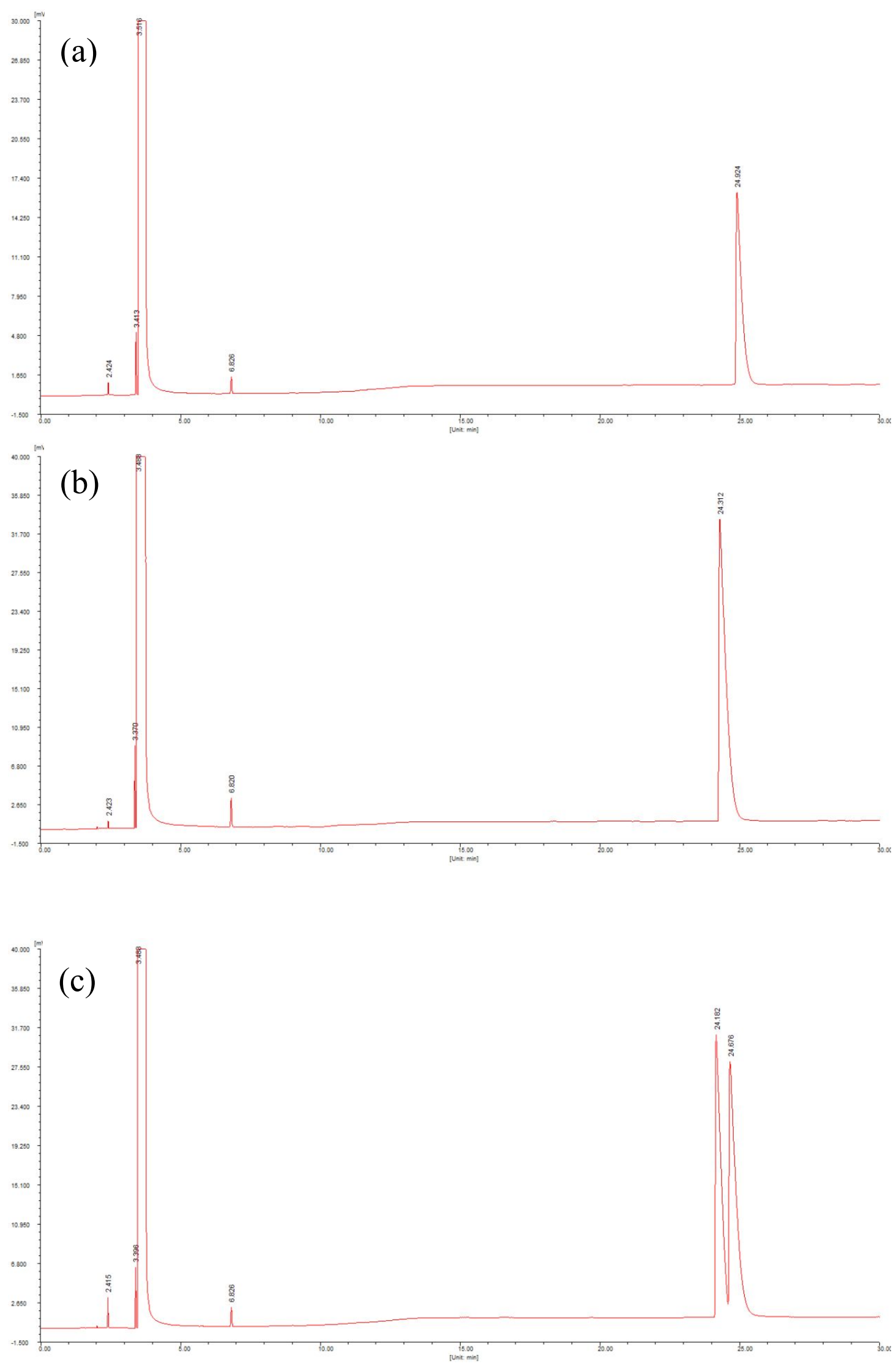


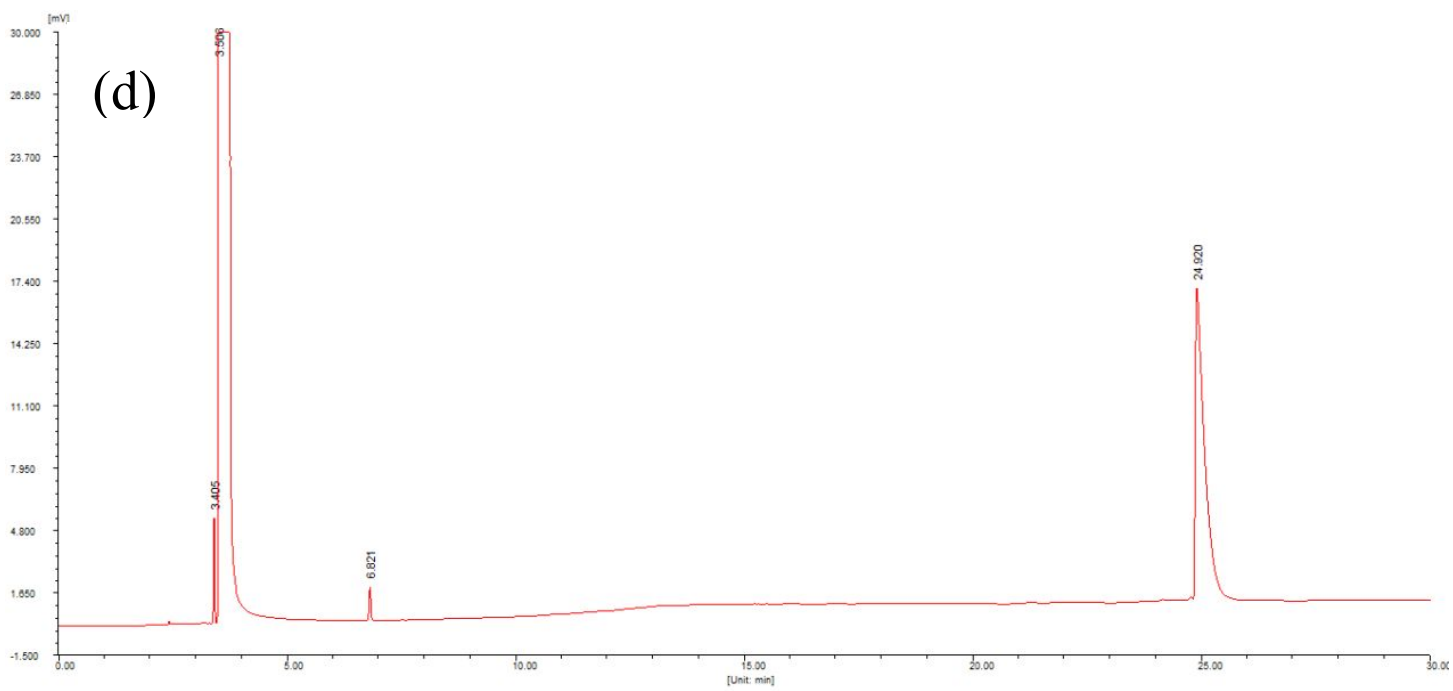

Figure S5. GC analysis of the ee values of the product. (a) (R)-3-quinuclidinol standard.

(b) (S)-3-quinuclidinol standard. (c) (R/S)-3-quinuclidinol standard mixture. (d) the product in this study. 


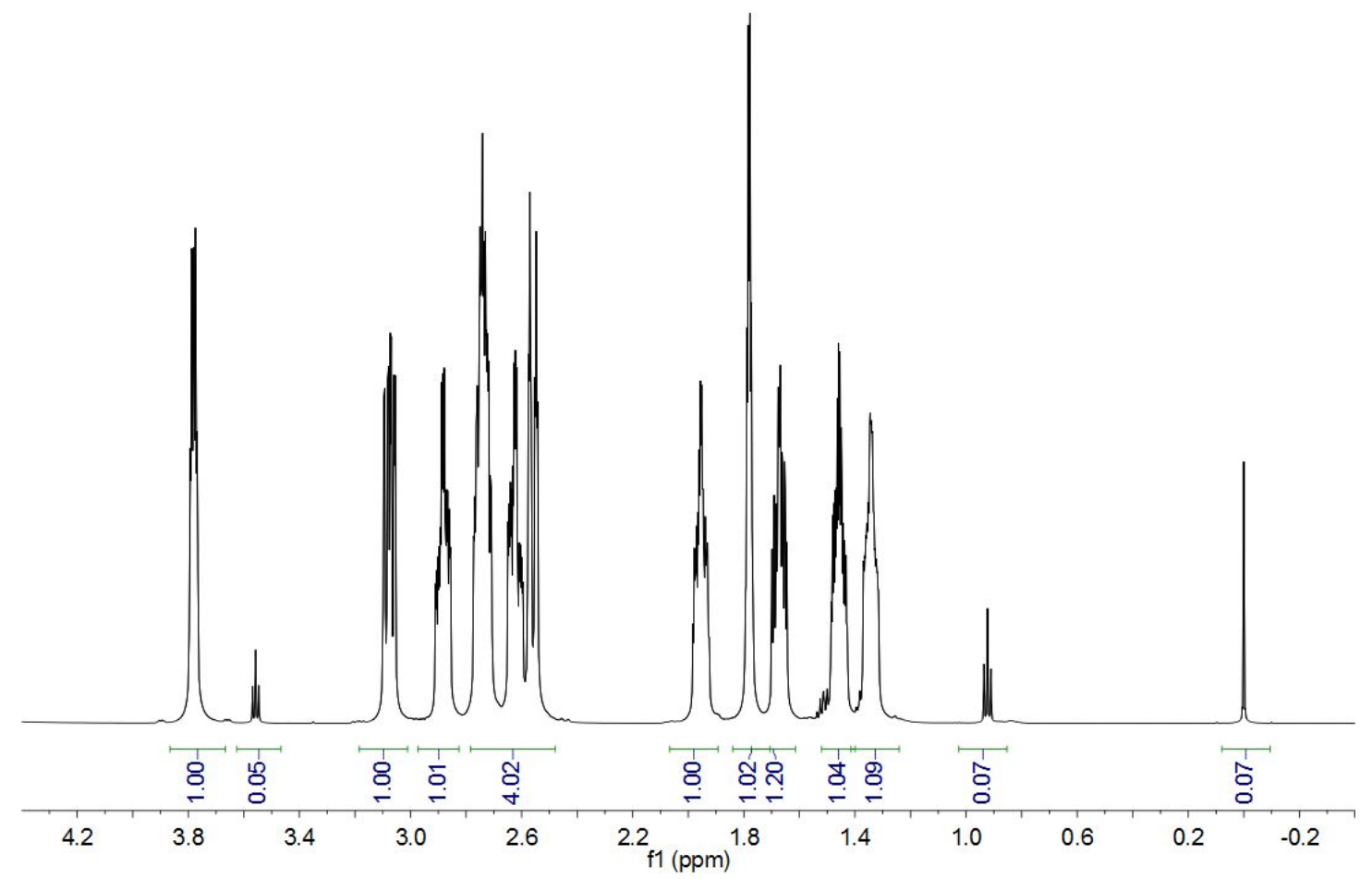

Figure S6. ${ }^{1} \mathrm{H}$ NMR of (R)-3-quinuclidinol. $\delta 4.81(\mathrm{~s}, 1 \mathrm{H}), 3.78(\mathrm{~m}, 1 \mathrm{H}), 3.10(\mathrm{~m}, 1 \mathrm{H})$, $2.90(\mathrm{~m}, 1 \mathrm{H}), 2.66(\mathrm{~m}, 4 \mathrm{H}), 1.95(\mathrm{~m}, 1 \mathrm{H}), 1.78(\mathrm{~m}, 1 \mathrm{H}), 1.69(\mathrm{~m}, 1 \mathrm{H}), 1.46(\mathrm{~m}, 1 \mathrm{H})$, $1.34(\mathrm{~m}, 1 \mathrm{H})$. 


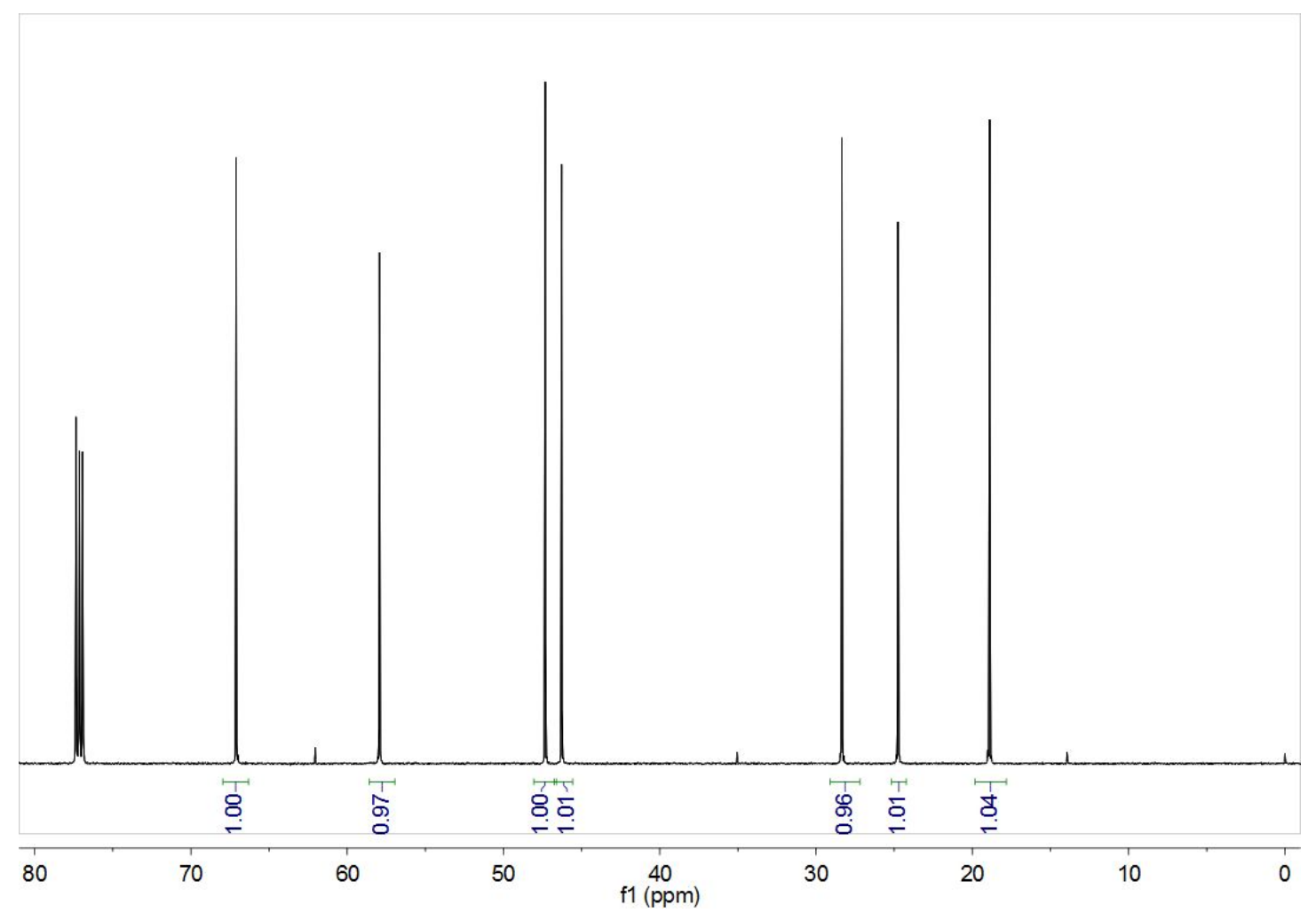

Figure S7. ${ }^{13} \mathrm{CNMR}$ of (R)-3-quinuclidinol. $\delta 67.1(\mathrm{CH}), 57.9\left(\mathrm{CH}_{2}\right), 47.3\left(\mathrm{CH}_{2}\right), 46.3$ $\left(\mathrm{CH}_{2}\right), 28.3(\mathrm{CH}), 24.7\left(\mathrm{CH}_{2}\right), 18.9\left(\mathrm{CH}_{2}\right)$. 